\title{
DOES RAMADAN FASTING AFFECT DIURNAL VARIATION ON SWIMMING PERFORMANCE AND ANAEROBIC POWER?
}

\author{
Salah Ferchichi ${ }^{1,2 i}$, \\ Yana Taktak ${ }^{3}$ \\ ${ }^{1}$ Higher Institute of Sport and Physical Education, \\ Ksar-Said, Manouba University, \\ Manouba, Tunisia \\ 2Department of Physiology and Lung Function Testing, \\ Sousse Faculty of Medicine, \\ University of Center, \\ Sousse, Tunisia \\ ${ }^{3}$ Higher Institute of Sport and Physical Education, \\ Kef Jendouba University, \\ Kef, Tunisia
}

\section{Abstract:}

The aim of this study is to see whether Ramadan fasting has an effect on the diurnal variations in anaerobic power and swimming performance or not. Ten participants whose mean \pm SE for age, height, body mass are $19.4 \pm 1.4$ years, $1.72 \pm 0.1 \mathrm{~m}$ and $72.8 \pm$ $6.6 \mathrm{~kg}$, respectively. They are tested at 3 testing periods [i.e., one week before Ramadan (BR), the middle period of Ramadan (MPR), the end period of Ramadan (EPR)], tests are performed at 07:00 $\mathrm{h}$ and 17:00 $\mathrm{h}$ throughout every course. The test sessions were started with oral temperature and body mass measurements. Regularly doing first the Wingate test then a 25-m swim at maximal speed at each test session. During the three experimental periods, dietary intake was assessed. The result shows a significant diurnal variation of muscle power and fatigue throughout the Wingate test before Ramadan. Likewise, there is a daily rhythm in the stroke parameters and swimming performance in the mentioned period. These diurnal variations change during the month of Ramadan with a decrease in power output, swim performance, swim speed and stroke length in the evening, with no changes for the morning tests. Moreover, the diurnal variations of muscle fatigue during the three morning tests show no changes and remain the same. Whereas the three evening tests show a gradual increase towards tiredness. The results show that Ramadan may has a great effect on the circadian rhythm of muscle power and swimming performance. The time-of-day effects the anaerobic power variables during the normal days which disappear during Ramadan. Ramadan fasting effects performance in the evening; however, the morning performance tests are unchangeable during

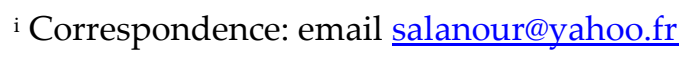


Ramadan. Additionally, Ramadan fasting has no adverse effect on energy intake, and percentages of macronutrient intake.

Keywords: circadian variation, crawl, energy intake, stroke parameters, Wingate test

\section{Introduction}

Circadian rhythm is called the biological/circadian clock.The term circadian is derived from Latin words, circa (approximate) and dies (day), denoting approximately "one day" and refers to behavioral, physiological, and molecular changes with a cycle length of approximately 24 h (Susman et al., 2007; Vitale \& Weydahl, 2017). Various physiological and psychological functions have been shown to changes during the solar day (Atkinson \& Reilly, 1996; Gueldich et al., 2019), and the existence of circadian rhythms in human performance is well established (Souissi, Gauthier, Sesboüé, Larue, \& Davenne, 2004). The circadian rhythm of performance has received a great deal of attention (Atkinson \& Reilly, 1996; Küüsmaa-Schildt et al., 2019; López-Samanes et al., 2017; Tiwari, \& Deol, 2016), with evidence of changes in anaerobic physical performance with time of day (Souissi \& Davenne, 2004; Souissi et al., 2007; Souissi et al., 2010). Whereas, the literature generally indicates an early morning nadir and a peak performance in the late afternoon (Chtourou \& Souissi, 2012).

Variety of factors can influence the intra-daily variations of performances, such as the time of day of training (Souissi et al., 2002; Souissi \& Davenne, 2004; Souissi et al., 2010), morningness-eveningness chronotype and sleep-wake pattern (Kerkhof, Korving, Willemse-vd Geest, \& Rietveld, 1980; Rossi, Formenti, Vitale, Calogiuri, \& Weydahl, 2015). The term chronotype refers to the individual differences in the timing of the sleep/wake as measured (Horne \& Ostberg, 1976), morningness-eveningness questionnaire (MEQ). The MEQ comprises 19 questions regarding wake-up times and bedtimes, appropriate times for physical and mental activities, and state of consciousness before going to bed and immediately after waking. Among the 19 questions, 10 are answered on a 5-point scale, and 9 are multiple-choice questions with a score range of 14 points. The total score is the MEQ score. Depending on the MEQ score, circadian typology was classified into five categories: definitely morning type (70-86 points), moderately morning type (59-69 points), intermediate type (42-58 points), moderately evening type (31-41 points), and definitely evening type (19-30 points). Morning-type individuals have earlier sleep-wake schedules, earlier diurnal peaks of alertness and performance and earlier sleep propensity rhythms than evening-type individuals (Horne, Brass, \& Pettitt, 1980; Natale \& Cicogna, 1996).

It has also been reported that the diurnal variation increase in core temperature may exert a beneficial passive warm-up that may enhance metabolic reactions, increase the extensibility of connective tissue, reduce muscle viscosity, and increase conduction velocity of action potentials (Shephard, 1984). 
Likewise natural or phenomenal factors, such as nutrition habits, Ramadan fasting and the length of fasting day may alter the circadian system (Horne et al. 1980; Souissi, Gauthier, Sesboüé, Larue, \& Davenne, 2004; Vitale \& Weydahl, 2017). All along Ramadan, several Muslims refrain from feeding or drinking during sunlight hours and eat the main meal after sundown during the sacred month, which lasts thirty days. After puberty, all healthy Muslims are required to abstain from food. In addition, Muslims consume a greater variety of foods during Ramadan compared with the rest of the year (Hallak \& Nomani, 1988). Some Muslims consume an additional meal before sleeping (Roky, Chapotot, Hakkou, Benchekroun, \& Buguet, 2001). Also, sugary foods and drinks are consumed more frequently throughout Ramadan (Fedail, Murphy, Salih, Bolton, \& Harvey, 1982). Behavioral modifications are therefore involved with meal planning and shortening period allowed for sleep and may affect upon a person's physiology, organic chemistry, and lifestyle (Chaouachi, Leiper, Souissi, Coutts, \& Chamari, 2009b; Waterhouse, 2010).

Therefore, it was found that Ramadan fasting leads to changes in the metabolic status including blood glucose and lipid (Al-Rawi et al., 2020; Kul, Savas, Oztürk, \& Kar, 2014; Taileb, \& Saidaissa, 2018). Previous studies demonstrated a significant reduction in sports performance during Ramadan, compared to the pre-Ramadan period (Aloui et al., 2013; Chtourou et al., 2011; Hammouda et al., 2013). Also, it has been demonstrated that Ramadan fasting induce to a degradation in muscular performances (Bigard, Boussif, Chalabi, \& Guezennec, 1998). Wilson, Drust, \& Reilly (2009) noted that agility and ability of sprint in football players are affected by Ramadan fasting. However, it is reported that Ramadan fasting did not affect sports performance when the athletes maintained the same training load during this month (Chaouachi et al., 2009a; Karli, Guvenc, Aslan, Hazir, \& Acikada, 2007). Likewise, authors reported no remarkable change in sprint performance of qualified soccer players throughout Ramadan (Zerguini, Kirkendall, Junge, \& Dvorak, 2007)

The divergences between the results of these studies could be due to the time-ofday variations in testing. Indeed, Souissi et al. (2007) demonstrated that the influences of Ramadan fasting on muscular performances are dependent on the time-of-day of the measurements. Those authors confirmed that muscle power during the Wingate and force-velocity trials through Ramadan had been affected in the evening, nevertheless, the morning performances were unchangeable with comparison to pre-Ramadan performances. Moreover, the time-of-day effects the anaerobic power variables which disappear during Ramadan. However, more investigations are required to determine the effects of Ramadan on circadian rhythm and on physical performance.

In swimming, maximal muscle strength at a given velocity [i.e., power] and stroke parameters [i.e., swim speed $(V)$, stroke rate $(S R)$ and stroke length $(S L)$ ] are factors of great importance for performance. Also, morning-evening differences increase with the complexity of motor tasks; this effect has been reported not only with regard to overall performance but also with regard to its different components, such as maximal power and technical ability (Ferchichi et al., 2015, 2016). 
In view of the above considerations, the aim of the study is to examine the effect of Ramadan fasting on the diurnal variations of maximal cycle power and stroke parameters and consequently on swimming performance. We are not aware of any experimental evidence regarding effects of Ramadan fasting on the diurnal variations in stroke parameters in front crawl swimmers and overall swimming performance, and so the present study attempts to provide insights in this area. We hypothesized that Ramadan fasting would induce a reduction in swimming and physical performances in the evening. Moreover, we hypothesized that muscle fatigue would be higher in the evening during Ramadan.

\section{Material and Methods}

\subsection{Participants}

Ten participants volunteered for this study, they were students in the Higher Institute of Sport and Physical Education. All were members of the University swimming team whose mean \pm SE for age, height, body mass were $19.4 \pm 1.4$ years, $1.72 \pm 0.1 \mathrm{~m}$ and $72.8 \pm$ $6.6 \mathrm{~kg}$, respectively. The participants were considered healthy and had no medical contraindications that could influence the results of the study. They were categorized either as "moderately morning type" ( $n=2)$ or as "neither type" $(n=8)$, on the basis of their answers to Horne and Ostberg (1976) self-assessment questionnaire. The criteria for inclusion were that before Ramadan they kept standard times for sleep (between 23:00 and 7:00 \pm 1:00 h). During Ramadan participants were consuming food later at night, they took their last meal at $02: 00 \mathrm{~h}$.

\subsection{Experimental design}

The participants were tested at 3 testing periods [i.e., one week before Ramadan (BR), the middle period of Ramadan (MPR), the end period of Ramadan (EPR)], the instructions and procedures were identical in all tests. Participants performed tests at 07:00 $\mathrm{h}$ and 17:00 h during each period, but only one test session per day and with a recovery period of at least $36 \mathrm{~h}$ between successive test sessions. The test sessions were started with oral temperature and body mass measurements. The oral temperature became recorded by way of a digital thermometer (Omron ${ }^{\circledR}$, Paris, France; accuracy $\pm 0.05{ }^{\circ} \mathrm{C}$ ) in the beginning of each testing session, then body mass was measured using a digital scale (Tanita, Tokyo, Japan). Wingate test and a 25-m swim at maximal velocity using the front crawl stroke were also completed in the same order at each test session. The interval between completing the Wingate test and starting the $25-\mathrm{m}$ swim test was $30 \mathrm{~min}$. The Wingate test was selected because it is a common test of anaerobic power and capacity (Granier, Mercier, Mercier, Anselme, \& Préfaut, 1995).

\subsection{Energy intake}

The participants were required to register their meals intakes in a diary over a span of three days for every period of physical testing (BR, MPR, and EPR). The records were 
analyzed by a nutritionist using a computerized nutrition system, the Food Processor, Nutrition and Fitness Software, ESHA Research, Professional Nutrition Analysis Software and Databases (2002-2003).

\subsection{Wingate test}

The Wingate test was realized on a friction-loaded cycle ergometer (Monark 894 E, Stockholm, Sweden) interfaced with a microcomputer. It is performed in a 30-second time span at a maximal sprint, against a constant resistance related to body mass $(0.087 \mathrm{~kg} \bullet \mathrm{kg}$ ${ }^{1}$ body mass) as proposed by Bar-Or (1987). Every second, power output was calculated and stored by the computer. The peak power output (PP) attained over $1 \mathrm{~s}$, the mean power (MP) over the entire $30 \mathrm{~s}$, and the Fatigue Index (FI) have been recorded and saved for further analysis. FI (i.e., the percentage of decrease in power output) was equal to the difference between the highest (PP) and lowest power (LP) divided by the highest power:

$\mathrm{FI}(\%)=[(\mathrm{PP}-\mathrm{LP}) / \mathrm{PP}] * 100$

\subsection{Stroke parameters}

The front crawl stroke swum at a specific swim speed requires the application of an effective swimming technique. Swim speed (V) is definite by stroke length and stroke rate, and crucially physiological determinants (Craig \& Pendergast, 1979). In front crawl, the mathematical equation to calculate swim speed (in $\mathrm{m}_{\mathrm{s}} \mathrm{s}^{-1}$ ) is stroke rate ( $\mathrm{SR}$ in stroke. $\mathrm{min}^{-1}$ ) multiplied by stroke length (SL in m.stroke ${ }^{-1}$ ), as seen in this formula:

$\mathrm{V}=(\mathrm{SR} \times \mathrm{SL}) * 60$

\subsection{Video analyses}

One camera filmed each swimmer from above the pool and measured the time taken over a mean distance $12.5 \mathrm{~m}$ (from $10 \mathrm{~m}$ to $22.5 \mathrm{~m}$ ), using the swimmer's head as the marker, to assess swim speed $\left(\mathrm{V}, \mathrm{m} . \mathrm{s}^{-1}\right)$. As used by Chollet, Chalies, \& Chatard (2000), An underwater video cameras (Sony compact FCB-IX 10/P) with a rapid shutter speed $(1 / 1000 \mathrm{~s})$ were used at a rate of $50 \mathrm{~Hz}$, filmed the swimmer from the right-hand, stroke rate $\left(\mathrm{SR}\right.$, stroke. $\left.\mathrm{min}^{-1}\right)$ was calculated from the number of video frames required to perform three complete right arm strokes (3ST): $S R=3 / 3 S T$. Stroke length (SL, m.stroke1) was calculated from the SR and V according to the formula: SL =V/SR (Costill et al., 1985; Craig \& Pendergast, 1979).

\subsection{Statistical analyses}

Data were analyzed using a two-way ANOVA [3 (Ramadan) x 2 (time-of-day)] with repeated measures. When appropriate, significant differences between means were tested using the Least Significant Different (LSD) Fisher's post-hoc test. Data for the morning-evening differences were analyzed using a one-way analysis of variance with repeated measures [3 (Ramadan)]. The data are expressed in mean $( \pm S D)$, and the 
significance level was set at $\mathrm{p}<0.05$. All statistical tests were processed using (SPSS 20.0.0).

\section{Results}

\subsection{Energy intake}

The 1-way analysis of variance (ANOVA) that was conducted to compare daily energy intake showed no significant difference in mean energy and percentages of macronutrient intake before Ramadan, during MPR and EPR (Table 1).

Table 1: Mean $( \pm S D)$ values for Energy intake and Proportion of Carbohydrate, Lipid and Protein before Ramadan (BR), during the middle period of Ramadan (MPR) and in the end period of Ramadan (EPR), $(n=10)$

\begin{tabular}{lcccc} 
& BR & MPR & EPR & Ramadan \\
\hline Energy intake (Kcal.d-1) & $3010 \pm 362$ & $3062 \pm 435$ & $3031 \pm 336$ & $\mathrm{~F}_{(2,18)}=1.79, \mathrm{p}>0.05$ \\
Carbohydrate (\%) & $54.79 \pm 2.85$ & $54.41 \pm 2.61$ & $54.36 \pm 2.54$ & $\mathrm{~F}_{(2,18)}=2.27, \mathrm{p}>0.05$ \\
Lipid (\%) & $31.37 \pm 1.41$ & $31.47 \pm 1.46$ & $31.2 \pm 1.75$ & $\mathrm{~F}_{(2,1)}=1.37, \mathrm{p}>0.05$ \\
Protein $(\%)$ & $13.84 \pm 1.54$ & $14.12 \pm 1.37$ & $14.44 \pm 1.09$ & $\mathrm{~F}_{(2,18)}=2.14, \mathrm{p}>0.05$ \\
\hline
\end{tabular}

\subsection{Body mass and temperature}

Mean body mass and temperature values in the morning and evening during BR, MPR and EPR are presented in (Table 2). The two-way ANOVA (Ramadan $x$ time of day) for body mass showed no significant effects for Ramadan or for time-of-day ( $\mathrm{p}>0.05)$.

Oral temperature showed a significant Time-of-day effect $\left(\mathrm{F}_{(1.9)}=1822, \mathrm{p}<0.001\right)$. There was no significant effect of Ramadan $\left(\mathrm{F}_{(2.18)}=0.57, \mathrm{p}>0.05\right)$. There was significant difference in oral temperature between morning and evening during BR, MPR and EPR $(\mathrm{t}=-61, \mathrm{p}<0.001, \mathrm{t}=-51, \mathrm{p}<0.001 ; \mathrm{t}=-16.6, \mathrm{p}<0.001$ respectively), these results demonstrating that oral temperature was higher at 17:00 $\mathrm{h}$ than 07:00 during the 3 periods of testing. During Ramadan, in comparison with BR, oral temperature was not affected in the morning $\left(\mathrm{F}_{(2.18)}=2.9, \mathrm{p}>0.05\right)$. Likewise oral temperature was not different between the evening sessions $\left(\mathrm{F}_{(2.18)}=1.63, \mathrm{p}>0.05\right)$.

Table 2: Mean values $( \pm$ SD) for oral temperature and body mass $(n=10)$ in the morning (at 07:00 h) and evening (17:00 h) before Ramadan (BR), during the middle period of Ramadan (MPR) and in the end period of Ramadan (EPR)

\begin{tabular}{|c|c|c|c|c|}
\hline & & BR & MPR & EPR \\
\hline \multirow[t]{2}{*}{ Temperature $\left({ }^{\circ} \mathrm{C}\right)$} & morning & $36.3 \pm 0.4$ & $36.3 \pm 0,4$ & $36.2 \pm 0.4$ \\
\hline & evening & $36.9 \pm 0.4^{* * *}$ & $36.8 \pm 0.4^{* * *}$ & $36.9 \pm 0.5^{* * *}$ \\
\hline \multirow[t]{2}{*}{ Body mass $(K g)$} & morning & $72.8 \pm 6.6$ & $72.6 \pm 6.7$ & $72.6 \pm 6.5$ \\
\hline & evening & $72.5 \pm 6.4$ & $72.3 \pm 6.4$ & $72.4 \pm 6.8$ \\
\hline
\end{tabular}

\footnotetext{
***: significant differences between morning and evening during the same phase, at the level of $p<0.001$.
} 


\subsection{Wingate test}

\subsubsection{Power output}

There was significant effect of Ramadan $\left(\mathrm{F}_{(2.18)}=31.64, \mathrm{p}<0.001\right)$, Time-of-day $\left(\mathrm{F}_{(1.9)}=\right.$ 11.7, $\mathrm{p}<0.01)$ effect and significant Ramadan $\mathrm{x}$ Time-of-day interaction $\left(\mathrm{F}_{(2.18)}=11.39, \mathrm{p}<\right.$ 0.01). There was significant difference in power output(PP) between morning and evening during $B R(t=-4.07, p<0.01)$, while no differences were detected between morning and evening during MPR and EPR $(t=-0.07, p>0.05 ; t=-0.04, p>0.05$ respectively). The significant Ramadan effect indicate that(PP) was higher during $\mathrm{BR}$ than MPR and EPR ( $<0.001)$ (figure 1).

Figure 1: Power output (mean $\pm \mathrm{SD}$ ) recorded at 07:00 and 17:00 h during BR, MPR and EPR. ** : significant difference between 07:00 and 17:00 $\mathrm{h}$ at the level of $\mathrm{p}<0.01 ;++,+++$ : significant difference in comparison with BR at the level of $p<0.01$ and $p<0.001$, respectively

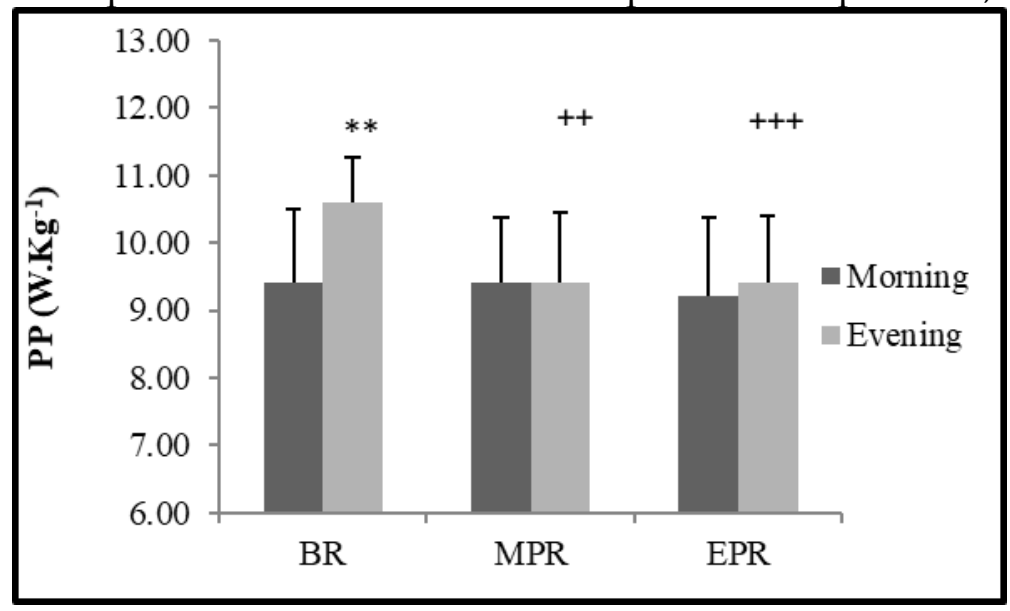

Further analyses indicated that the increased (PP) generated at 17:00 h during BR were debilitated during MPR and EPR, while no differences were observed in those parameters at 07:00 $\mathrm{h}$ at any of the testing periods.

\subsubsection{Mean power}

There was significant effect of Ramadan $\left(\mathrm{F}_{(2.18)}=16.97, \mathrm{p}<0.001\right)$ and significant Ramadan $x$ Time-of-day interaction $\left(\mathrm{F}_{(2.18)}=6.03, \mathrm{p}<0.05\right)$. In contrast, there was no significant Time-of-day $\left(\mathrm{F}_{(1.9)}=1.4, \mathrm{p}>0.05\right)$ effect. There was significant difference in mean power(MP) between morning and evening during BR $(\mathrm{t}=-4.05, \mathrm{p}<0.01)$, while no differences were detected between morning and evening during MPR and EPR $(t=1.19$, $p>0.05 ; t=-1.24, p>0.05$ respectively). The significant Ramadan effect indicate that (MP) was higher during BR than MPR and EPR $(\mathrm{p}<0.001)$ (figure 2). Further analyses indicated that the increased (MP) produced at 17:00 h during BR were blunted during MPR and EPR, while no differences were detected in these parameters at 07:00 $\mathrm{h}$ at any of the testing periods. 
Figure 2: Mean power (mean $\pm \mathrm{SD}$ ) recorded at 07:00 and 17:00 $\mathrm{h}$ during BR, MPR and EPR. ** : significant difference between 07:00 and 17:00 $\mathrm{h}$ at the level of $\mathrm{p}<0.01 ;+,++$ : significant difference in comparison with BR at the level of $\mathrm{p}<0.05$ and $\mathrm{p}<0.001$, respectively

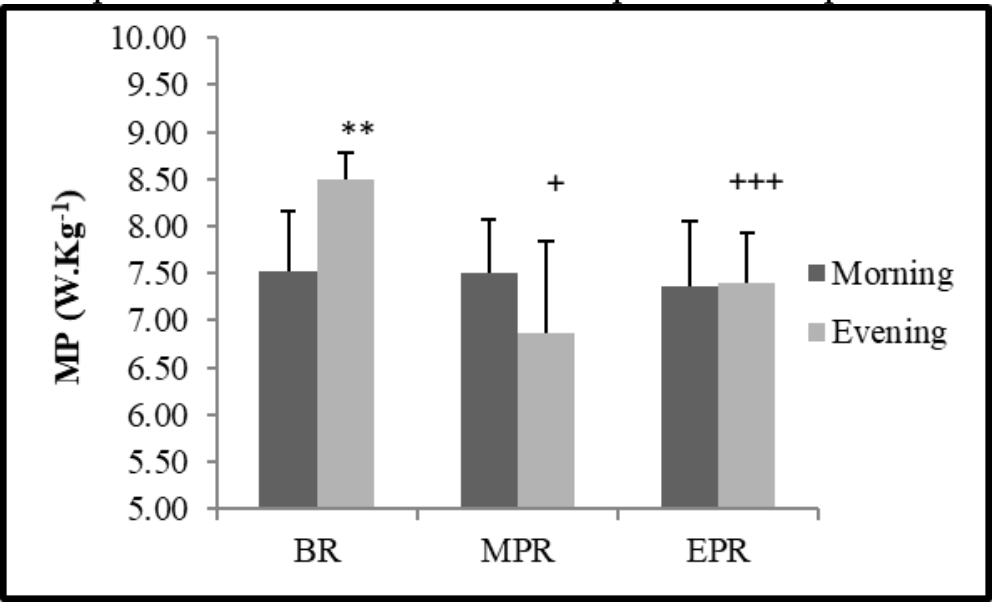

\subsubsection{Fatigue index}

There was significant effect of Ramadan $\left(\mathrm{F}_{(2.18)}=12.44, \mathrm{p}<0.001\right)$, Time-of-day $\left(\mathrm{F}_{(1.9)}=\right.$ 187.73, $\mathrm{p}<0.001)$ effect and significant Ramadan $x$ Time-of-day interaction $\left(\mathrm{F}_{(2.18)}=14.17\right.$, $\mathrm{p}<0.001)$. There was significant difference in fatigue index $(F I)$ between morning and evening during BR, MPR and EPR $(\mathrm{t}=-3.65, \mathrm{p}<0.01, \mathrm{t}=-8.17, \mathrm{p}<0.001 ; \mathrm{t}=-9.17, \mathrm{p}<$ 0.001 respectively), these results demonstrating that the (FI) was higher at 17:00 $\mathrm{h}$ than 07:00 during the 3 periods of testing(figure 3).

Figure 3: Fatigue index $(\%)($ mean $\pm \mathrm{SD})$ recorded at 07:00 and 17:00 $\mathrm{h}$ during $\mathrm{BR}$, MPR and EPR. **,*** : significant difference between 07:00 and 17:00 $\mathrm{h}$ at the level of $\mathrm{p}<0.01$ and $\mathrm{p}<0.001$, respectively;,++++ : significant difference in comparison

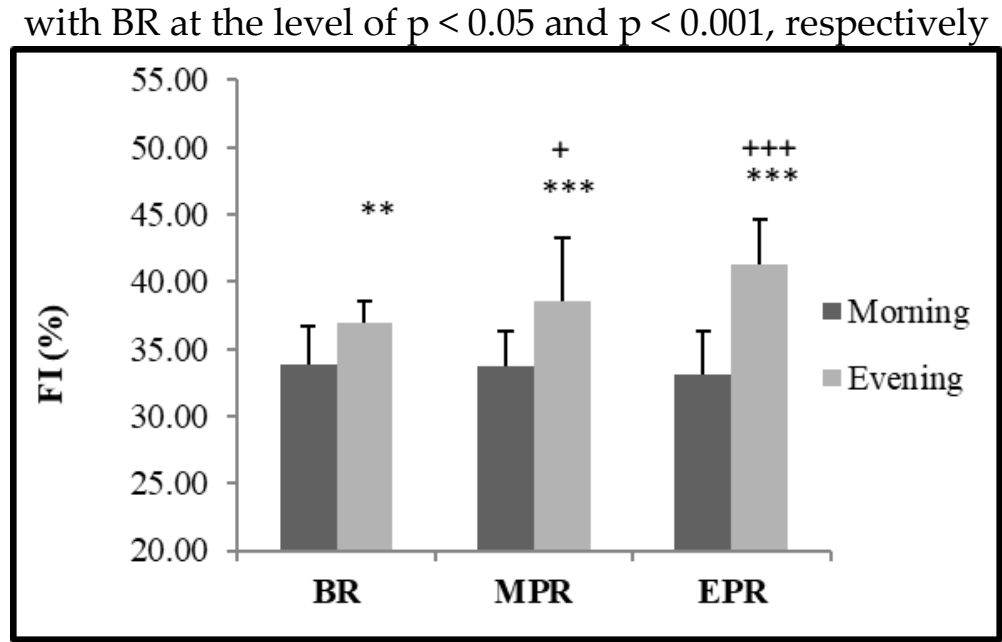

The significant Ramadan effect indicate that (FI) increased significantly during Ramadan compared with that before Ramadan $(\mathrm{p}<0.001)$. Moreover, Ramadan appeared to modify the diurnal variation of muscle fatigue by increasing the morning-evening 
differences from BR to the MPR and EPR ( $-2.62 \pm 2.26 ;-7.25 \pm 2.8 ;-9.39 \pm 3.24 \%$ respectively).

\subsection{Swim performance and stroke parameters}

\subsubsection{Swim performance}

There was significant effect of Ramadan $\left(\mathrm{F}_{(2.18)}=7.84, \mathrm{p}<0.01\right)$, Time-of-day $\left(\mathrm{F}_{(1.9)}=47.69\right.$, $\mathrm{p}<0.001)$ effect and no significant Ramadan $\mathrm{x}$ Time-of-day interaction $\left(\mathrm{F}_{(2.18)}=2.25, \mathrm{p}>\right.$ 0.05). There was significant difference in performance $(P)$ between morning and evening during BR, MPR and EPR $(\mathrm{t}=6.05, \mathrm{p}<0.001, \mathrm{t}=5.41, \mathrm{p}<0.01 ; \mathrm{t}=6.73, \mathrm{p}<0.001$ respectively), these results demonstrating that $(P)$ was higher at 17:00 $\mathrm{h}$ than 07:00 during the 3 periods of testing(figure 4 ).

Figure 4: Performance (mean $\pm \mathrm{SD}$ ) recorded at 07:00 and 17:00 $\mathrm{h}$ during $\mathrm{BR}$, MPR and EPR. ${ }^{* *}, * * *$ : significant difference between 07:00 and 17:00 $\mathrm{h}$ at the level of $p<0.01$ and $p<0.001$, respectively;,+++ : significant difference in comparison with $B R$ at the level of $p<0.05$ and $p<0.01$, respectively

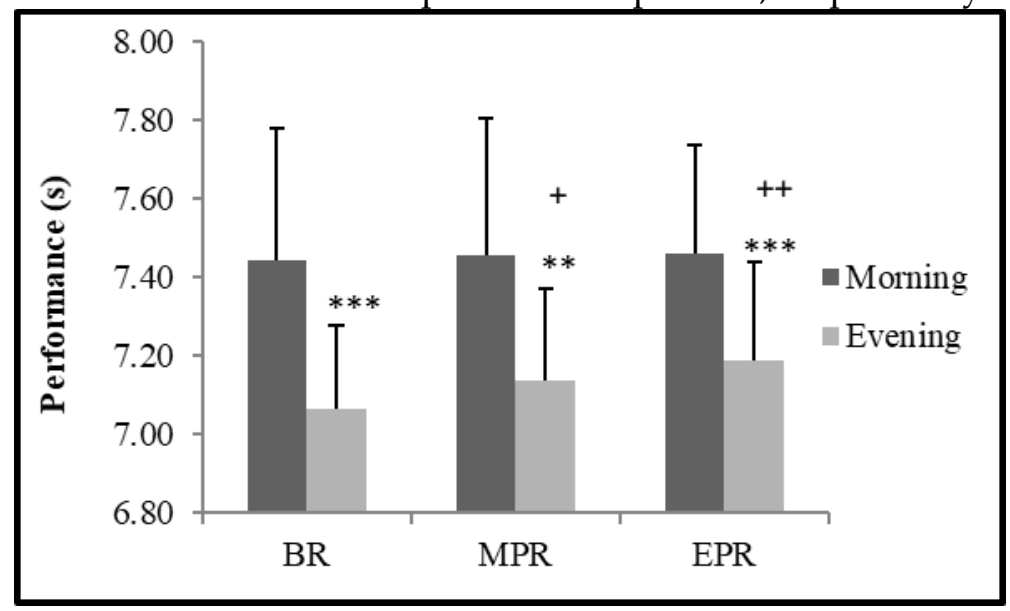

The significant Ramadan effect indicated that $(P)$ was higher during BR than MPR $(\mathrm{p}<0.05)$ and EPR $(\mathrm{p}<0.001)$. There was significant difference of $(P)\left(\mathrm{F}_{(2.18)}=10.94, \mathrm{p}<\right.$ $0.01)$ between the evening sessions. While, between morning sessions there was no significant difference $\left(\mathrm{F}_{(2.18)}=0.13, \mathrm{p}>0.05\right)$.

\subsubsection{Swim speed}

There was significant effect of Ramadan $\left(\mathrm{F}_{(2.18)}=8.62, \mathrm{p}<0.01\right)$, Time-of-day $\left(\mathrm{F}_{(1.9)}=61.01\right.$, $\mathrm{p}<0.001)$ effect and no significant Ramadan $x$ Time-of-day interaction $\left(\mathrm{F}_{(2.18)}=1.88, \mathrm{p}>\right.$ 0.05). There was significant difference in swim speed $(\mathrm{V})$ between morning and evening during BR, MPR and EPR $(\mathrm{t}=-6.79, \mathrm{p}<0.001, \mathrm{t}=-6, \mathrm{p}<0.001 ; \mathrm{t}=-6.72, \mathrm{p}<0.001$ respectively), these results demonstrating that $(V)$ was higher at 17:00 $\mathrm{h}$ than 07:00 during the 3 periods of testing (figure 5). The significant Ramadan effect indicated that (V) was higher during BR than MPR $(p<0.05)$ and EPR $(p<0.001)$. ). There was significant difference of $(\mathrm{V})\left(\mathrm{F}_{(2.18)}=10.28, \mathrm{p}<0.01\right)$ between the evening sessions. While, between morning sessions there was no significant difference $(F(2.18)=0.38, p>0.05)$. 
Figure 5: Swim speed (mean $\pm \mathrm{SD}$ ) recorded at 07:00 and 17:00 $\mathrm{h}$ during BR, MPR and EPR. *** : significant difference between 07:00 and 17:00 $\mathrm{h}$ at the level of $\mathrm{p}<0.001 ;+,+$ : significant difference in comparison

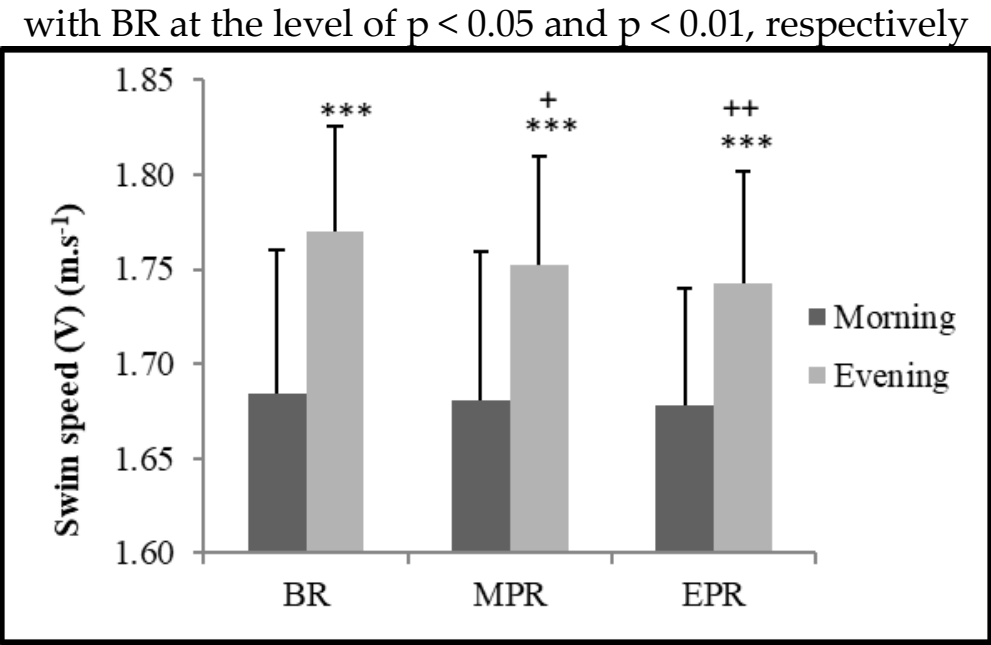

\subsubsection{Stroke rate}

There were significant Time-of-day $\left(\mathrm{F}_{(1.9)}=25, \mathrm{p}<0.01\right)$ effect and no significant effect of Ramadan $\left(\mathrm{F}_{(2.18)}=0.28, \mathrm{p}>0.05\right)$ or Ramadan $\mathrm{x}$ Time-of-day interaction $\left(\mathrm{F}_{(2.18)}=2.71, \mathrm{p}\right.$ $>0.05)$. There was significant difference in stroke rate (SR) between morning and evening during BR, MPR and EPR $(\mathrm{t}=-4.04, \mathrm{p}<0.01, \mathrm{t}=-5.23, \mathrm{p}<0.01 ; \mathrm{t}=-5.51, \mathrm{p}<0.01$ respectively), these results demonstrating that (SR) was higher at 17:00 $\mathrm{h}$ than 07:00 during the 3 periods of testing(figure 6). There was no significant Ramadan effect indicated that no difference of (SR) during BR compared to MPR and EPR ( $p>0.05)$.

Figure 6: Stroke rate (mean $\pm \mathrm{SD}$ ) recorded at 07:00 and 17:00 $\mathrm{h}$ during $\mathrm{BR}$, MPR and EPR. ** : significant difference between 07:00 and 17:00 $\mathrm{h}$ at the level of $\mathrm{p}<0.01$

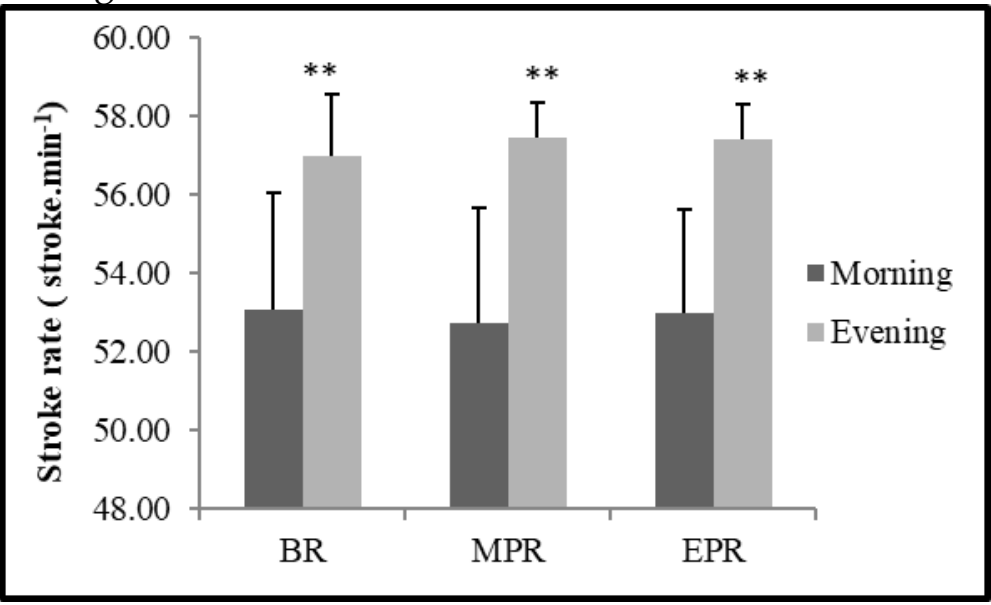

\subsubsection{Stroke length}

There were no significant Time-of-day $\left(\mathrm{F}_{(1.9)}=4.73, \mathrm{p}>0.05\right)$ effect, but there were significant effect of Ramadan $\left(\mathrm{F}_{(2.18)}=5.18, \mathrm{p}<0.05\right)$ and significant Ramadan $\mathrm{x}$ Time-ofday interaction $\left(\mathrm{F}_{(2.18)}=4.57, \mathrm{p}<0.05\right)$. There was no significant difference in stroke 
length(SL) between morning and evening during BR, MPR and EPR (all, $\mathrm{p}<0.05$ ) (figure 7).

Figure 7: Stroke length (mean $\pm \mathrm{SD}$ ) recorded at 07:00 and 17:00 h during BR, MPR and EPR. + : significant difference in comparison with BR at the level of $p<0.05$

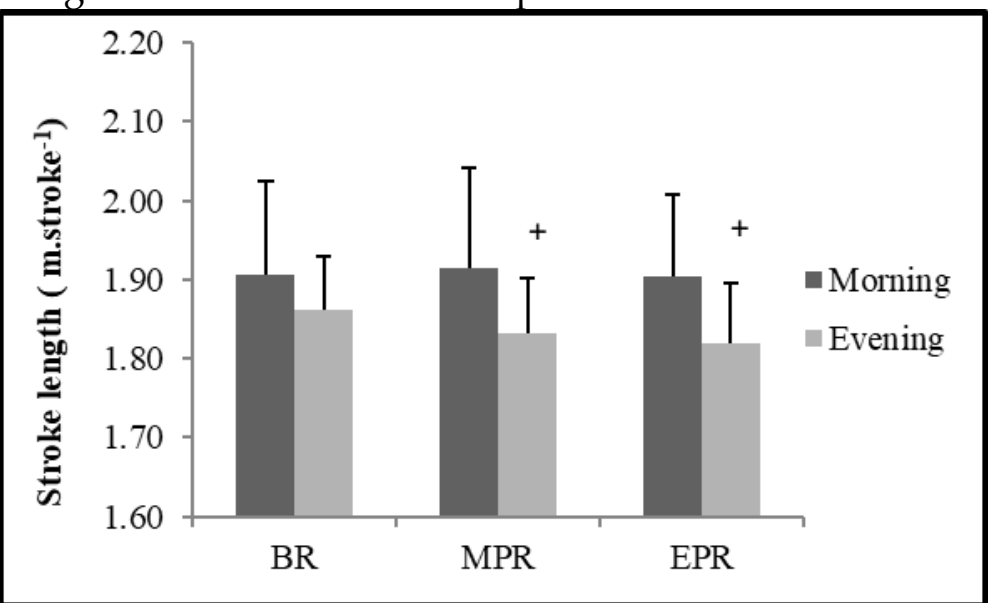

The significant Ramadan effect indicated that (SL) was higher during BR than EPR $(p<0.05)$, but no difference between BR and MPR $(p>0.05)$. ). However, there was significant difference of $(\mathrm{SL})\left(\mathrm{F}_{(2.18)}=9.22, \mathrm{p}<0.01\right)$ between the evening sessions. While, between morning sessions there was no significant difference $\left(F_{(2.18)}=0.69, p>0.05\right)$.

\section{Discussion}

This study was designed to examine the effect of Ramadan fasting on the diurnal variation of anaerobic power and swimming performance. The results showed a significant diurnal variation of muscle power and fatigue during the Wingate test before Ramadan. Likewise, one major finding was that stroke parameters and swimming performance showed a daily rhythm before Ramadan. These diurnal variations were modified during the month of Ramadan with a decrease in power output, swim performance, swim velocity and stroke length in the evening, with no changes for the morning tests. Furthermore, the diurnal variations of muscle fatigue increased during MPR and EPR only for the evening test sessions.

\subsection{Effect of time-of-day before Ramadan}

Before Ramadan, power output and mean power were higher in the evening than in the morning these results are consistent with previous reports (Hill \& Smith 1991; Melhim 1993; Souissi, Gauthier, Sesboüé, Larue, \& Davenne, 2004).Similar results were found by (Bernard, Giacomoni, Gavarry, Seymat, \& Falgairette, 1998), who observed an increase of $5-7 \%$ between morning and evening. A higher rate of adenosine triphosphate (ATP) turnover could partially explain such an increase in maximal power. It is well known that maximal power output is supported by energy deriving mainly from phosphocreatine 
and anaerobic glycogenolysis (Gaitanos, Williams, Boobis, \& Brooks, 1993). Moreover, a maximal sprint on a cycle ergometer resulted in a fivefold increase in plasma epinephrine concentrations and a twofold increase in plasma norepinephrine (Bogdanis, Nevill, Lakomy, \& Boobis, 1998; Gaitanos, Williams, Boobis, \& Brooks, 1993). The sympathoadrenal activity, and thus the plasma epinephrine level (Linsell et al. 1985), demonstrated diurnal rhythms, probably subsumed by a circadian oscillator (Refinetti, Kaufman, \& Menaker, 1994). Because peak epinephrine values were obtained in the early evening, this could explain the better performance noted at that moment in a short-term, high-intensity exercise.

However, these findings do not agree with previous data that showed that (FI) during the Wingate test was independent of time-of-day or higher in the morning than in the evening (Lericollais, Gauthier, Bessot, Sesboüé, \& Davenne, 2009; Souissi et al., 2010). It has been suggested that the strong level of motivation required from participants to perform the multiple $30 \mathrm{sec}$ Wingate test might interfere with the results and therefore minimize the time-of-day effect (Reilly \& Down, 1992).

In addition, data indicate that swimming performance was better in the evening than the morning, with higher evening values for V and SR, possibly explaining the better swimming performance at this time. Circadian variations in maximum swimming performance have previously been shown in other studies (Baxter \& Reilly, 1983; Ferchichi et al., 2015, 2016; Kline et al., 2007). In the present study, even though V was significantly higher in the evening compared to the morning, the mechanisms responsible for such variation are poorly understood. It has been suggested that better evening performances may be linked to changes in body temperature (Atkinson \& Reilly, 1996; Drust, Waterhouse, Atkinson, Edwards, \& Reilly, 2005). As well, the present study showed that kinetic aspects of performance (SR and SL) were influenced by the time of day. It has been also suggested that the diurnal increase in body temperature may be responsible for the diurnal increase in performance (Souissi et al., 2007).Even if the exact mechanisms of relationship are not recognized, it has been indicated that higher body temperature may intensify metabolic reactions, raise the extensibility of connective tissue, moderate muscle viscosity, and augment conduction velocity of potential (Souissi, Gauthier, Sesboüé, Larue, \& Davenne, 2004). In agreement, data from the current study showed that oral temperature was higher in the evening than the morning at each test period.

\subsection{Effect of Ramadan}

1) The current study showed that physical performances were unaffected by Ramadan fasting in the morning. However, it was also demonstrated that Ramadan fasting was associated with reduced physical performances [i.e., power output $(P P)$, swim performance $(P)$, swim velocity $(V)$ and stroke length $(S L)]$ and increased muscle fatigue (FI) in the evening compared with the pre-Ramadan (BR).

2) The decrease in performance during Ramadan does not necessarily relate to changes in dietary intake. Indeed, in agreement with previous studies (Aloui et al., 
2013; Chtourou et al., 2011; Meckel, Ismaeel, \& Eliakim, 2008), the estimated total daily energy intake and relative proportions of carbohydrates, lipid, and protein in the diet did not change in our experiment during Ramadan.

3) Additionally, other studies showed that daily total energy intake and body mass did not differ significantly during Ramadan compared to BR (Beltaifa et al., 2002; Boukhris et al., 2019). Among reasons for performance decline might be the change in sleep patterns. In this study, participants noticed that their sleep duration was reduced because they were consuming food later at night, they took their last meal at 02:00 $\mathrm{h}$ during Ramadan. The large meal in the evening is likely to hinder sleep onset, which may reduce nocturnal sleep (Waterhouse, 2010).

4) In agreement with the results of the present study, Chaouachi et al. (2009b) reported higher fatigue scores during Ramadan. During a normal day, fatigue has been shown to be higher in the evening than morning (Chtourou et al., 2011; Nicolas, Gauthier, Bessot, Moussay, \& Davenne, 2005), and this time-of-day effect could have been enhanced during Ramadan, leading to a diminished capacity to maintain effort at the supreme level.

The present results demonstrated also that stroke length, swim speed and swim performance is affected only in the evening but not in the morning during Ramadan, which may be explained by the same phenomenon. These determinations recommend that Ramadan might act straightly on the circadian rhythm of anaerobic performance by affecting both the acrophase and amplitude of the advanced circadian rhythm. Nevertheless, significant decreases were recorded both in anaerobic power and in stroke parameters during the month of Ramadan compared with that before Ramadan (BR). These decreases likely explain the respective lowest swimming velocity in the evening. Furthermore, the diurnal variations of muscle fatigue increased during the second week and at the end of Ramadan but only for the evening test sessions.

\section{Conclusion}

In conclusion, our result suggest that Ramadan may act directly on the circadian rhythm of muscle power and swimming performance by decreasing in power output, swim performance, swim velocity and stroke length, and by increasing of muscle fatigue during the evening test sessions, with no changes for the morning tests. In order to maximize training benefits and avoid overreaching or/and overtraining during Ramadan, coaches should be aware of the likely changes in circadian rhythms that the intermittent fast can cause, and consider modifying the training programme variables (e.g., intensity, volume, and frequency) especially when such sessions are scheduled in the evening hours. In addition, in this study, participants were consuming food later at night, they took their last meal at 02:00 $\mathrm{h}$ during Ramadan. It has been reported that a lack of sleep or a sleep deprivation affect performance either when it is examined during the course of the day or when comparing Ramadan to normal diet periods. Therefore, upcoming investigations should take these factors into consideration. 


\section{Acknowledgements}

We wish to express our gratitude to the participants who volunteered for this study.

\section{Conflict of Interest statement}

The authors declare that they have no conflict of interest related to the study or preparation of the manuscript.

\section{About the Authors}

Salah Ferchichi, PhD, Department of Sport and Physical Education, Ksar-Said, Manouba University, Manouba, Tunisia. Research interests: chronobiology of exercise performance, Physiology, sports science, sport performance.

Yana Taktak, PhD, Department of Sport and Physical Education, Kef, Jendouba University, Kef, Tunisia. Research interests: education and sport performance.

\section{References}

Aloui, A., Chaouachi, A., Chtourou, H., Wong, DP., Haddad, M., Chamari, K., \& Souissi N. (2013). Effects of Ramadan on the Diurnal Variations of Repeated Sprints Performances. Int J Sports Physiol Perform, 8(3), 254-262.

Al-Rawi, N., Madkour, M., Jahrami, H., Salahat, D., Alhasan, F., BaHammam, A., \& AlIslam Faris, M. (2020). Effect of diurnal intermittent fasting during Ramadan on ghrelin, leptin, melatonin, and cortisol levels among overweight and obese subjects: A prospective observational study. PloS one, 15(8), e 0237922.

Atkinson, G., \& Reilly, T. (1996). Circadian variation in sports performance. Sports Med, 21(4), 292-312.

Beltaifa, L., Bouguerra, R., Ben Slama, C., Jabrane, H., El Khadhi, A., Rayana, B., Doghri, T. (2002). Food intake, and anthropometrical and biological parameters in adult Tunisians during Ramadan. EMHJ-Eastern Mediterranean Health Journal, 8(4-5), 603-611.

Bar-Or, O. (1987). The Wingate anaerobic test an update on methodology, reliability and validity. Sports Med, 4(6), 381-394.

Baxter, C., \& Reilly, T. (1983). Influence of 4 times of day on all-out swimming. Br J Sports Med, 17(2), 122-127.

Bernard, T., Giacomoni, M., Gavarry, O., Seymat, M., \& Falgairette, G. (1998). Time-ofday effects in maximal anaerobic leg exercise. Eur. J. Appl. Physiol, 77(1-2), 133-138.

Bessot, N., Moussay, S., Clarys, JP., Gauthier, A., Sesboüé, B., \& Davenne, D. (2007). The influence of circadian rhythm on muscle activity and efficient force production during cycling at different pedal rates. J Electromyogr Kinesiol, 17(2), 176-83.

Bigard, A. X., Boussif, M., Chalabi, H., \& Guezennec, C. Y. (1998). Alterations in muscular performance and orthostatic tolerance during Ramadan. Aviation Space and Environmental Medicine, 69(4), 341-346. 
Bogdanis, G. C., Nevill, M. E., Lakomy, H. K., \& Boobis, L. H. (1998). Power output and muscle metabolism during and following recovery from 10 and $20 \mathrm{~s}$ of maximal sprint exercise in humans. Acta Physiol. Scand, 163(3), 261-272.

Boukhris, O., Hsouna, H., Chtourou, L., Abdesalem, R., BenSalem, S., Tahri, N., Trabelsi, K., Stannard, S. R., Chtourou, H. (2019). Effect of Ramadan fasting on feelings, dietary intake, rating of perceived exertion and repeated high intensity short-term maximal performance. Chronobiology international, 36(1), 1-10.

Chaouachi, A., Coutts, A. J., Chamari, K., Wong, Del P., Chaouachi, M., Chtara, M., Roky, R., \& Amri, M. (2009b). Effect of Ramadan intermittent fasting on aerobic and anaerobic performance and perception of fatigue in male elite judo athletes. $J$ Strength Cond Res, 23(9), 2702-2709.

Chaouachi, A., Leiper, J. B., Souissi, N., Coutts, A. J., \& Chamari, K. (2009a). Effects of Ramadan intermittent fasting on sports performance and training: A Review . Int J Sports Physiol Perform, 4(4), 419-434.

Chollet, D., Chalies, S., \& Chatard, J. C. (2000). New index of coordination for the crawl: Description and usefulness. Int J Sports Med, 21(1), 54-59.

Chtourou, H., \& Souissi, N. (2012). The effect of training at a specific time-of-day: a review. J Strength Cond Res, 26(7), 1984-2005.

Chtourou, H., Hammouda, O., Souissi, H., Chamari, K., Chaouachi, A., \& Souissi, N. (2011). The effect of Ramadan fasting on physical performances, mood state and perceived exertion in young footballers. Asian J Sports Med, 2(3), 177-185.

Costill, D. L., Kovaleski, J., Porter, D., Kirwan, J., Fielding, R., \& King, D. (1985). Energy expenditure during front crawl swimming: Predicting success in middle-distance events. Int J Sports Med, 6(5), 266-270.

Craig, A. B., \& Pendergast, D. R. (1979). Relationships of stroke rate, distance per stroke, and velocity in competitive swimming. Med Sci Sports Exerc, 11(3), 278-283.

Drust, B., Waterhouse, J., Atkinson, G., Edwards, B., \& Reilly, T. (2005). Circadian rhythms in sports performance-an update. Chronobiol Int, 22(1), 21-44.

Fedail, S. S., Murphy, D., Salih, S. Y., Bolton, C. H., \& Harvey, R. F. (1982). Changes in certain blood constituents during Ramadan. Am J Clin Nutr, 36(2), 350-353.

Ferchichi, S., Taktak, H., Taktak, Y., Zarrouk, F., Tabka, Z., \& Souissi, N. (2015). Diurnal variation in stroke parameters and motor organization in front-crawl swimmers. Biological Rhythm Research, 46(6), 887-895.

Ferchichi, S., Taktak, Y., Taktak, H., Chtourou, H., Zarrouk, F., Tabka, Z., \& Souissi, N. (2016). The effect of training at the same time-of-day on the diurnal variations of technical ability and swimming performance. Biological Rhythm Research, 47(3), 447-461.

Gaitanos, G. C., Williams, C., Boobis, L. H., \& Brooks, S. (1993). Human muscle metabolism during intermittent maximal exercise. J. Appl. Physiol, 75(2), 712-719.

Granier, P., Mercier, B., Mercier, J., Anselme, F., \& Préfaut, C. (1995). Aerobic and anaerobic contribution to Wingate test performance in sprint and middle-distance runners. Eur J Appl Physiol, 70(1), 58-65. 
Gueldich, H., Zghal, F., Borji, R., Chtourou, H., Sahli, S., Rebai, H. (2019). The effects of Ramadan intermittent fasting on the underlying mechanisms of force production capacity during maximal isometric voluntary contraction. Chronobiology International, 36(5), 698-708.

Hallak, M. H., \& Nomani, M. Z. (1988). Body weight loss and changes in blood lipid levels in normal men on hypocaloric diets during Ramadan fasting. Am J Clin Nutr, 48(5), 1197-1210.

Hammouda, O., Chtourou, H., Aloui, A., Chahed, H., Kallel, C., Miled, A., Chamari, K., Chaouachi, A., \& Souissi, N. (2013). Concomitant Effects of Ramadan Fasting and Time-Of-Day on Apolipoprotein AI, B, Lp-a and Homocysteine Responses during Aerobic Exercise in Tunisian Soccer Players. PLOS One, 8(11), e79873.

Hill, D. W., \& Smith, J. C. (1991). Circadian rhythm in anaerobic power and capacity. Can J Sport Sci, 16(1), 30-32.

Horne J. A., \& Ostberg O. (1976). A self-assessment questionnaire to determine morningness-eveningness in human circadian rhythms. Int. J. Chronobiol, 4(2), 97110.

Horne, J. A., Brass, C. G., \& Pettitt, A. N. (1980). Circadian performance differences between morning and evening "types". Ergononmics, 23(1), 29-36.

Karli, U., Guvenc, A., Aslan, A., Hazir, T., \& Acikada, C. (2007). Influence of Ramadan fasting on anaerobic performance and recovery following short time high intensity exercise. J Sports Sci Med, 6(4), 490-497.

Kerkhof, G. A., Korving, H. J., Willemse-vd Geest, H. M., \& Rietveld, W. J. (1980). Diurnal differences between morning-type and evening-type subjects in self-rated alertness, body temperature and the visual and auditory evoked potential. Neurosci Lett, 16(1), 11-15.

Kline, C. E., Durstine, J. L., Davis, J. M., Moore, T. A., Devlin, T. M., Zielinski, M. R., \& Youngstedt, S. D. (2007). Circadian variation in swim performance. J Appl Physiol, 102(2), 641-649.

Kul, S., Savas, E., Oztürk, Z. A., \& Karadag, G. (2014). Does Ramadan fasting alter body weight and blood lipids and fasting blood glucose in a healthy population? A meta-analysis. J Relig Health, 53(3), 929-942.

Küüsmaa-Schildt, M., Liukkonen, J., Vuong, M. K., Nyman, K., Häkkinen, K., Häkkinen, A. (2019). Effects of morning vs evening combined strength and endurance training on physical performance, sleep and well-being. Chronobiology International, 36(6), 811-825.

Lericollais, R., Gauthier, A., Bessot, N., Sesboüé, B., \& Davenne, D. (2009). Time-of-day effects on fatigue during a standard anaerobic test in well-trained cyclists. Chronobiol Int, 26(8), 1622-1635.

Linsell, C. R., Lightman, S. L., Mullen, P. E., Brown, M. J., \& Causon, R. C. (1985). Circadian rhythms of epinephrine and norepinephrine in man. J. Clin. Endocrinol. Metab, 60(6), 1210-1215. 
López-Samanes, Á., Moreno-Pérez, D., Maté-Muñoz, J. L., Domínguez, R., Pallarés, J. G., Mora-Rodriguez, R., \& Ortega, J. F. (2017). Circadian rhythm effect on physical tennis performance in trained male players. Journal of sports sciences, 35(21), 21212128.

Meckel, Y., Ismaeel, A., \& Eliakim, A. (2008). The effect of the Ramadan fast on physical performance and dietary habits in adolescent soccer players. Eur J Appl Physiol, 102(6), 651-657.

Melhim, A. F. (1993). Investigation of circadian rhythms in peak power and mean power of female physical education students. Int. J. Sports Med, 14(6), 303-306.

Natale, V., \& Cicogna, P. (1996). Circadian regulation of subjective alertness in morning and evening "types". Person Individ Diff, 20(4), 491-497.

Nicolas, A., Gauthier, A., Bessot, N., Moussay, S., \& Davenne, D. (2005). Time-of-day effects on myoelectric and mechanical properties of muscle during maximal and prolonged isokinetic exercise. Chronobiol Int, 22(6), 997-1011.

Racinais, S., Chamari, K., Hachana, Y., Bartagi, Z., Blonc, S., \& Hue, O. (2006). Effect of acute and dry exposure in moderately warm and humid environment on muscle performance at different times of day. Int J Sports Med, 27(1), 49-54

Refinetti, R., Kaufman, C. M., \& Menaker, M. (1994). Complete suprachiasmatic lesions eliminate circadian rhythmicity of body temperature and locomotor activity in golden hamsters. J. Comp of Physiol A, 175, 223-232.

Reilly, T., \& Down, A. (1992). Investigation of circadian rhythms in anaerobic power and capacity of the legs. J. Sports. Med. Phys. Fitness, 32(4), 343-347.

Reilly, T., Atkinson, G., Edwards, B., Waterhouse, J., Farrelly, K., \& Fairhurst, E. (2007). Diurnal variation in temperature, mental and physical performance, and tasks specifically related to football (soccer). Chronobiol Int, 24(3), 507-519.

Roky, R., Chapotot, F., Hakkou, F., Benchekroun, M. T., \& Buguet, A. (2001). Sleep during Ramadan intermittent fasting. J Sleep Res, 10(4), 319-327.

Rossi, A., Formenti, D., Vitale, J. A., Calogiuri, G., \& Weydahl, A. (2015). The Effect of Chronotype on Psychophysiological Responses during Aerobic Self-Paced Exercises. Perceptual and Motor Skills, 121(3), 840-855.

Shephard, R. J. (1984). Sleep, biorhythms and human performance. Sports Med, 1(1), 1137.

Souissi, N., \& Davenne, D. (2004). Circadian rhythms and anaerobic performance. Sci Motricité, 53, 39-55.

Souissi, N., Driss, T., Chamari, K., Vandewalle, H., Davenne, D., Gam, A., Fillard, J. R., \& Jousselin, E. (2010). Diurnal variation in Wingate test performance: influence of active warm up. Chronobiol Int, 27(3), 640- 652.

Souissi, N., Gauthier, A., Sesboüé, B., Larue, J., \& Davenne, D. (2004). Circadian rhythms in two types of anaerobic cycle leg exercise: Force-velocity and 30-s Wingate tests. Int J Sports Med, 25(1), 14-19. 
Souissi, N., Gauthier, A., Sesboüé, B., Larue, J., \& Davenne, D. (2002). Effects of regular training at the same time of day on diurnal fluctuations in muscular performance. Journal of Sports Sciences, 20(11), 929-937.

Souissi, N., Souissi, H., Sahli, S., Tabka, Z., Dogui, M., Ati, J., Davenne, D. (2007). Effect of Ramadan on the diurnal variation in short-term high power output. Chronobiol Int, 24(5), 991-1007.

Susman, E. J., Dockray, S., Schiefelbein, V. L., Herwehe, S., Heaton, J. A., \& Dorn, L. D. (2007). Morningness/eveningness, morning-to-afternoon cortisol ratio, and antisocial behavior problems during puberty. Dev Psychol, 43(4), 811-822.

Taileb, S., \& Saidaissa, K. (2018). Impact De L'exercice Aerobie Combine Au Jeune Du Ramadan Sur Quelques Indices Biologiques Lies A La Sante Chez Les Femmes/Impact Of Combined Aerobics Exercise During Ramadan On Some Related Biological Health Indices In Women. European Journal of Physical Education and Sport Science.

Tiwari, L. M., \& Deol, N. S. (2016). Diurnal Variation on The Performance of Coordinative Abilities of Soccer Players. European Journal of Physical Education and Sport Science.

Vitale, J. A., \& Weydahl, A. (2017). Chronotype, physical Activity, and Sport Performance: A Systematic Review. Sports Med, 47(9), 1859-1868.

Waterhouse, J. (2010). Effects of Ramadan on physical performance: chrono-biological considerations. Br J Sports Med, 44(7), 509-515.

Wilson, D., Drust, B., \& Reilly, T. (2009). Is diurnal lifestyle altered during Ramadan in professional Muslim athletes? Biol Rhythms Res, 40(5), 385-397.

Zerguini, Y., Kirkendall, D., Junge, A., \& Dvorak, J. (2007). Impact of Ramadan on physical performance in professional soccer players. Br J Sports Med, 41(6), 398400 . 
Salah Ferchichi, Yana Taktak

DOES RAMADAN FASTING AFFECT DIURNAL VARIATION

ON SWIMMING PERFORMANCE AND ANAEROBIC POWER?

Creative Commons licensing terms

Authors will retain the copyright of their published articles agreeing that a Creative Commons Attribution 4.0 International License (CC BY 4.0 ) terms will be applied to their work. Under the terms of this license, no permission is required from the author(s) or publisher for members of the community to copy, distribute, transmit or adapt the article content, providing a proper, prominent and unambiguous attribution to the authors in a manner that makes clear that the materials are being reused under permission of a Creative Commons License. Views, opinions and conclusions expressed in this research article are views, opinions and conclusions of the author(s). Open Access Publishing Group and European Journal of Physical Education and Sport Science shall not be responsible or answerable for any loss, damage or liability caused in relation to/arising out of conflict of interests, copyright violations and inappropriate or inaccurate use of any kind content related or integrated on the research work. All the published works are meeting the Open Access Publishing requirements and can be freely accessed, shared, modified, distributed and used in educational, commercial and non-commercial purposes under a Creative Commons attribution 4.0 International License (CC BY 4.0). 